Хохлова М. Г., Немова Т. В., Цвіліховський М. І.

UDK 636.09 : 616-08

\title{
FEATURES OF THE USE OF DOMESTIC ANIMALS IN THERAPEUTIC TARGETS
}

M. G. KHOKHLOVA, student of the Faculty of Veterinary Medicine T.V. NEMOVA, $\mathrm{PhD}$, associated professor

M. I. TSVILIKHOVSKIY, Academician of the Ukrainian academy of agrarian sciences, doctor in biology, professor

National University of Life and Environmental Sciences of Ukraine

E-mail: nemova tv@ukr.net

Abstract. Animal-assisted therapy is important treatment of many human diseases, it is demand in the developed countries of the world. The use of methods of animal-assisted therapy in medical practice has its own peculiarities which involve the use of non-directed animal assisted therapies which include interaction with animals at home without awareness or purposeful understanding of their therapeutic value, or the use of directed animal-assisted therapy which involves the purposeful use of animals and their symbols by specially designed therapeutic programs using specially trained animals. The aim was a thorough analysis methods hippotherapy, dolphin therapy, canis therapy, cat therapy, hirudotherapy, melissotherapy and features of their application in various areas of medical practice.

In this work the main mechanisms of action of animal-assisted therapy on the human body are analyzed and the range of diseases that are exposed to

Introduction. Nowadays, there are more non-traditional methods of the treatment are used in medicine. A special place among all those methods take animal-assisted therapy. therapeutic influence by animals is outlined. The high efficiency of using animal-assisted therapy for adults and children in solving a wide range of medical problems has been established. It is noted that the use of different types of animals during therapy can reduce stress, normalize the nervous system, promotes the harmonization of interpersonal relationships and interactions of the individual with the environment that promotes both mental and social rehabilitation and implementation of internal capacity rights.

Animal-assisted therapy, as a method of treating many diseases, has great prospects for application as well as a wide range of studies on the peculiarities of animal action on the human body.

Key words: animal-assisted therapy, hippotherapy, dolphin therapy, canisteriology, feline therapy, hirudotherapy, apitherapy, person.

Animal-assisted therapy (from the Latin "animal" - animal) is a kind of therapy that uses animals and their images to provide psychotherapeutic assistance. This is a scientific method of preventing serious illness and treating a 
Хохлова М. Г., Немова Т. В., Цвіліховський М. І.

person at the house of the animals images, pictures, fairy tale heroes, toys, as well as real animals [Ошибка! Источник ссылки не найден., Ошибка! Источник ссылки не найден.].

It is impossible to trace when the animal-assisted therapy arose, humans from ancient times live in association with nature, including a constant interaction with domesticated animals. In particular, it is known that in the 5th century BC Ancient Greek physician Hippocrates recommended practicing a medical horseback ride. The ancient Greeks found that dogs help people cope with various mental illnesses, but the Egyptians made cat in the rank of a deity for its amazing ability to treat the disease. Residents of India still believe that singing birds, especially nightingales, acts like antidepressants [Ошибка! Источник ссылки не найден.].

Analysis of recent researches and publications. Among the examples of animal-assisted therapy closer to our time, one can mention the successful experience of treating mental illness at the end of the 17th century in York (England).

Sigmund Freud used in his work a Chow Chow breed dog who was present at all his sessions [Ошибка! Источник ссылки не найден.].

Only in the second half of the 20th century, animal-assisted therapy received profound scientific substantiation and was recognized by the medical community as an independent method. of treatment through the actions of child therapist Boris Levinson who used dogs during therapeutic sessions for children [Ошибка! Источник ссылки не найден., Ошибка! Источник ссылки не найден.].

Today, animal-assisted therapy, thanks to many positive examples of treatment, has become an accepted methodology on a global scale. In several countries, such as the United States, Great Britain, Canada, and France, there are specialized medical associations that hold conferences, seminars and studies on topical issues regarding the use of animal-assisted therapy [Ошибка! Источник ссылки не найден.].

Purpose. The aim of the work was to generalize and analyze the literature on the specifics of the use of animals for the provision of therapeutic assistance to humans.

Results. Research results show that even the usual communication with animals without the use of special therapeutic techniques, has a positive effect on health - home pet owners are less prone to stress and, consequently, live longer.

According to researchers from the American University of Purdue, pets reduce the risk of death after myocardial infarction by $3 \%$. According to the scientists of the Australian Research Institute of the Baker Medical Research Institute, pet owners are less prone to hypertension and vascular disease. Scientists at the University of Missouri 
Хохлова М. Г., Немова Т. В., Цвіліховський М. І.

(USA) have shown that the level of serotonin (the "hormones of happiness") in the human body rises twice after person strokes a dog. According to statistics, $15 \%$ of British population suffer from allergies. The Japanese scientists (Japan's Himeji Medical Association) managed to establish that the owners of cats show a disease is $30 \%$ less often [Ошибка! Источник ссылки не найден.].

According to classification, there are two types of animal-assisted therapy:

1. Non-directed animal-assisted therapy - interaction with animals at home without awareness or purposeful understanding of their therapeutic value.

2. Directed animal-assisted therapy - purposeful use of animals and their symbols on specially designed therapeutic programs. For this type of animal-assisted therapy, specially trained animals are used, and not patient's animals. Directed animal-assisted therapy, is divided into different species - hippotherapy, dolphin therapy, canistherapy, feline therapy, and others.

The most widespread animal therapy is hippotherapy - the treatment in which people get help by riding horses. Since the late 50's of the twentieth century hippotherapy began to be used in the case of mental and neurological human diseases. Nowadays, centers for therapeutic riding have been set up in more than 45 countries in Europe and America [Ошибка! Источник ссылки не найден.].
Hippotherapy is used for disorders of the musculoskeletal system, atherosclerosis, craniocerebral traumas, poliomyelitis, gastrointestinal diseases, prostatitis, scoliosis, mental retardation. Communicating with the horse provides a stable positive emotional background that is in itself healing.

During riding, all major muscle groups are treated, the overall muscle tone of the body improves.

Hippotherapy is one of the most effective ways of recovery in the case of cerebral palsy (cerebral palsy). In addition, horseback riding has a psychotherapeutic effect. Hippocrates, for example, advice to ride horseback to the melancholic, since it frees a person from "dark thoughts" and causes "merry and clear thoughts". As an experiment, German scientists created a simulator that accurately repeats oscillatory movements of the horse, but the therapeutic effect was not noted, which confirms the leading role of communication with the animal [Ошибка! Источник ссылки не найден.].

Hippotherapy is considered one of the most promising methods of treatment for disabled persons since childhood. Through communication with the horse, autistic children become more open to the world, patients with oligophrenia begin to develop better, children with cerebrovascular accidents develop. A horse is not just a live simulator. For children with disabilities, the world of which is usually limited to their own 
Хохлова М. Г., Немова Т. В., Цвіліховський М. І.

apartment and the society of parents, communication with the horse causes a lot of positive emotions.

The minimum course of human treatment with the help of hippotherapy lasts for 1 year at an intensity of 1-3 lessons per week for 20-30 minutes. It should be agreed with specialist doctors. So far, there is no clear, scientifically substantiated explanation of how an ill person is influenced by communication with horses. The healing effect of hippotherapy is due to the fact that the rider begins to spin unilaterally with the horse, the lungs are revealed (this is especially important for patients with asthma). When the horse is walking, the rider pulse rises to $100-110$ beats per minute, while during the gallop - up to 170. In addition, at this time, the human heart muscle does not undergo serious organic changes, as from running, because the rider himself does not move, but responds to the motor impulse obtained from another living creature. The horse sends up to 110 such impulses per minute to the rider. Therefore, human muscles work like they cannot work on any training [Ошибка! Источник ссылки не найден.].

Hippotherapy sessions are allowed for animals not younger than 5-6 years of age, with a well-formed, balanced character, but not older than 13-14 years, as the age of the animal becomes a tougher step. For the medical ride select the most phlegmatic and addictive animals. It should be noted that horse riding is contraindicated in humans in the case of hemophilia, osteoporosis, injuries of the cervical and lumbar spine, distortions of the lumbar spine, diabetes and exacerbations of any chronic diseases of the gastrointestinal tract and kidneys.

Today's dolphin therapy is extremely in demand. As a rule, it is used for the rehabilitation of people, especially children with severe psychoneurological problems. Communication with dolphins helps to stabilize the psycho-emotional state of a person, to remove psychological tension. After communicating with the dolphin, a person calms down, begins to think unconventionally, quickly finds a way out of critical situation.

Dolphin therapy is a highly effective psychological rehabilitation for people who are in extreme conditions: survived earthquakes, hurricanes, accidents and any other severe stress. It is used to help people with cerebral palsy, Down's syndrome, autism. In addition, contact with dolphins treats people for depression, chronic fatigue syndrome, muscular asthenia, mental retardation, asthma, hearing impairment, cardiovascular and even tumor diseases

\section{[Ошибка! Источник ссылки не найден.].}

Dolphin therapy is based on several types of exposure. The ultrasound that emits dolphins, actively affects the brain, promotes blood circulation in the body and acts as an analgesic without harmful side effects, affects the activity of penetration of biologically active 
Хохлова М. Г., Немова Т. В., Цвіліховський М. І.

substances through the intercellular membrane [Ошибка! Источник ссылки не найден.].

Supplements the therapeutic effect of ultrasound on humans hydrodynamic effects due to finding in the flow of water and the emotional impact of communication and acquaintance with dolphin.

Dolphin therapy has adherents and opponents. Biologist Lori Morino has spent a significant amount of research at the University of Emory (USA) and expressed the view that there is no proven scientific effect of swimming with dolphins and the emotional impact of communicating with dolphins has the same therapeutic effect as any positive emotions that can be obtained other way [Ошибка! Источник ссылки не найден.].

However, parents of children with cerebral palsy and autism argue that after the course of dolphin therapy in children, there were significant shifts in behavior, language, movements, but not all children. Therefore, we can conclude that dolphin therapy has a greater psychological effect, which contributes to the improvement of the emotional background, processes of activation of processes in the brain and the intensification of the treatment process.

95\% of animals used in American psychotherapy - dogs. They are mainly used during rehabilitation of patients at houses of invalids, houses for the elderly, in hospitals of rehabilitation centers for children and adults. In contact with the dog during the game, or through special procedures, the patients reduce stress, blood pressure is normalize, psychological indicators change positively, anxiety is reduced, adaptability increases, depression is removed, coordination of movements improves in patients with cerebrovascular disease [Ошибка!

Источник ссылки не найден., Ошибка! Источник ссылки не найден., Ошибка! Источник ссылки не найден. ].

Dogs are wonderful "remedies" against hypodynamia, caused by a sedentary way of life. Walking with a dog reduces the probability of occurrence of cardiovascular diseases, myocardial infarction. They satisfy the shortage of people in communication, increase selfesteem of the owner, improve his companionship, help to solve conflicts in family. In dog (as in cat) saliva contains an enzyme lysozyme, which destroys pathogenic microorganisms [Ошибка! Источник ссылки не найден.].

It should be noted that nondirected anima-therapy with the use of dogs, has a positive therapeutic effect on the owner and his family in about $60 \%$ of cases in all age groups [Ошибка!

\section{Источник ссылки не найден.].}

No less important is feline therapy - treatment with cats. The cat is a unique animal, it accurately captures the mood of a person and his condition that can intervene in the treatment process as soon as the disease begins. However, the main condition for the positive effect of 
Хохлова М. Г., Немова Т. В., Цвіліховський М. І. the application of this method is the mutual love of man to the animal, good attitude towards it.

In connection with the peculiarity of the cat's nature, the main focus of feline therapy in medicine is the struggle against stress. Cats are less trained and less oriented towards humans than dogs, so they are less used to work with children.

According to statistics, cats owners go to doctors almost 5 times less often than those who do not have them. Cats, as scientists suggest, can "read" person's feelings and provide the therapeutic effect, basically, by the influence of their powerful biofield, which improves general well-being of almost any person, promotes the normal work of internal organs, positively affects the level of exchange substances According to studies, cats help in the treatment of a person for neuroses, depression, cardiovascular diseases, pathologies of the respiratory and digestive systems, dysfunctions of the musculoskeletal system, diseases of the endocrine and reproductive systems. In addition, twitching cats are excellent sound therapy. As it turned out, twitching accelerates the recovery of bone tissue in the event of fractures, eliminates pain during arthritis, osteochondrosis and other joint diseases, has a wound-healing effect [Ошибка! Источник ссылки не найден., Ошибка! Источник ссылки не найден.].

The biofield of the cat stabilizes the work of the heart, relieves the joints and headaches, stimulates the rapid healing of injuries, treats internal inflammatory diseases. The cat is an excellent energy information device that feels a change in the energy potential in the area of the pathological focus of the owner [Ошибка! Источник ссылки не найден.].

The therapeutic effect of cats depending on breed is investigated. In particular - long-haired cats (Angora, Persian, Siberian, Burmese, etc.) "neuropathologists", perfectly cope with irritability, depression and insomnia of the (owner); Persian cats can promote effective treatment of a person for osteochondrosis and joint pains; British or exotic shorthaired - "cardiologists", stabilize the activity of cardiovascular activity; short-haired and hide-free cats "specialize" in diseases of the kidneys, liver and gastrointestinal tract; Siamese cats contribute to the prevention of influenza and cold [Ошибка!

\section{Источник ссылки не найден.,}

\section{Ошибка! Источник ссылки не} найден.].

Specialists in "Cat therapy" argue that there are certain hours for the treatment of various diseases. Thus, the period from 03.00 to 05.00 hours is considered the most favorable for the treatment of pulmonary diseases, as well as diseases of the bronchi. But the gastrointestinal diseases are well exposed to therapy from 05.00 to 07.00 hours. Cardiovascular diseases are best treated from 11.00 to 13.00 hours, and tiredness can be removed only in the evening 
Хохлова М. Г., Немова Т. В., Цвіліховський М. І.

[Ошибка! Источник ссылки не найден.].

The time spent on "Cat therapy", it depends on the general condition of the patient's health, the stage of his disease, the presence of other diseases and some other factors: someone is enough to conduct a session for 5-10 minutes, and someone needs to keep the cat 1.5-2 hours.

The cat, going to a sick spot, becomes a kind of "living warmer", and while picking up his paws, she also makes a "massage". In addition, during contact with a cat's hair in human tissues there are weak electrical currents, thereby reducing the pressure, normalizing processes of excitation and inhibition in the nervous system [Ошибка! Источник ссылки не найден.].

The nasal cats are certain sound vibrations (frequency from 20 to 150 Hertz), which stimulate the healing process. Urethritis promotes increased body defenses, accelerates healing of wounds, as a result of the influence of sound vibrations of such a frequency, the density of bones increases, which contributes to fracturing. There is scientific evidence that cats are similar to acoustic ultrasound. It strengthens bones by $20 \%$ and stabilizes the cardiac rhythm. Nipping cats treat a person even for some mental illnesses [Ошибка! Источник ссылки не найден.].

Developed special recommendations for the use of felinotherapy, for example, for the treatment of a person for headache and high pressure, it is necessary to put the cat on the neck 3 times a day for 3-4 minutes; To treat a person for arrhythmias, it is necessary for a few minutes to stroke a cat or let her lie on the breast; For cardiac rhythm it is necessary to conduct sessions of "cocotherapy" every day for 10-14 days. In case of pain in the joints, the patient should be placed or put in a cat on the affected area of the body for 7-10 minutes per day for 30 days. To normalize blood pressure enough to iron your pet for 3-5 minutes.

However, it should be noted that there is no reliable evidence of the efficacy of felinotherapy for the treatment of inflammatory diseases, the repair of damaged tissues, diseases of the gastrointestinal tract and the cardiovascular system. According to some scientists, the results of felinotherapy are described due to the effect of placebo. Therefore, feline therapy for human treatment can be used only as an additional means in the framework of the basic, medical therapy prescribed by the doctor.

Apitherapy is the treatment of humans using bee venom and bee products (honey, cushion, wax, pollen (overgrowth), perg, propolis, royal jelly).

Apitherapy is a recognized medical therapy. The history of the method dates to ancient times. Another 5-7 thousand years ago, in India and China, the healing properties of honey, propolis and bites of bees, which treated a person for various 
Хохлова М. Г., Немова Т. В., Цвіліховський М. І.

poisonings, were used. Written memoirs dating back to 3,000 $\mathrm{BC}$ indicate that beekeeping and treating bees with bites have been well developed in Egypt. In Palestine, where many roaring hives lived in the rocks, on hot summer days, honey drooped down the rocks, so Palestine was called "a land where honey and milk flowing”. Doctor Galen 2000 years ago used apitherapy to relieve pain in the case of sciatica. Hippocrates (460$377 \mathrm{BC}$ ) wrote about the life of bees, the nutritional and medicinal qualities of beekeeping products. In his writings, he reported on the disinfecting, expectorant and continuing life of people properties of honey. He recommended honey to treat a person for purulent wounds, diseases of the stomach and liver

\section{[Ошибка! Источник ссылки не} найден.].

The scientific period of apitherapy begins in 1861, when professor Lukomsky M.I., based on his experience, published an article on "Bee poison as a cure for rheumatic fever". In 1887, Professor of the St. Petersburg Military Academy I. Lyubarsky published an article "The use of bee venom in military medical practice."

Since then, apitherapy has been widely used in medicine for human medicine for the treatment of osteochondrosis, coronary heart disease, hypertension, varicose veins, myocardial infarction, arrhythmias, rheumatism, radiculitis, neuritis, neuropathies, migraines, pain in different locations, a number of neurological syndromes, epilepsy, multiple sclerosis, the effects of craniocerebral traumas, paralysis and paresis, inflammatory diseases of the appendages, bronchial asthma, chronic bronchitis, the effects of pleurisy, arthritis, arthrosis, a number of skin diseases and other disorders.

Bee poison is the most powerful catalyst for physiological processes. One drop of that poison contains protein substances, 18 of the 20 essential amino acids, inorganic acids, almost the entire table of Mendeleev and many vitamins.

In small doses of bee venom has a beneficial effect on the body. Expands blood vessels, increases blood flow to the organs, improves metabolism. Peptides that are part of the bee venom, have a strong anti-inflammatory, analgesic, tonic effect.

Bee venom has analgesic effect, reduces cerebral edema, stimulates cerebral circulation, reduces nicotine and alcohol dependence, expands the bronchi, dilutes and removes sputum, increases the intestinal and stomach motility, stimulates the liver, reduces the pressure, increases the number of red blood cells, prevents the formation of blood clots in vessels In addition, bee venom has immunostimulant, bactericidal action, normalizes metabolism, protects against ionizing radiation. However, it should be remembered that bee venom can be deadly dangerous - a lethal dose for a person is about 0.2 grams. Therefore, bee poison is categorically contraindicated for people with tuberculosis, endocrine 
Хохлова М. Г., Немова Т. В., Цвіліховський М. І.

disorder, kidney or liver disease, exacerbation of acute or chronic infectious diseases, within one month of any vaccination; during pregnancy and feeding babies [Ошибка! Источник ссылки не найден.].

Hirudotherapy - treatment by medical leeches. Hirudotherapy is an effective remedy for varicose veins, thrombophlebitis, hypertension, angina pectoris, myocardial infarction, atherosclerosis, skin diseases, lungs, migraines, glaucoma, sinusitis, neuritis, bronchial asthma, gynecological and many other diseases.

The basis of the therapeutic effect of hirudotherapy is a saliva of leech, which contains a large number of biologically active substances that contribute to the normalization of internal homeostasis. It is a great anticoagulant, therefore it is used to prevent stroke and heart attack, trophic ulcers. Also noted are pronounced immunostimulant and antimicrobial action of hirudotherapy. Human treatment with leeches is effective for hemorrhoids, varicose veins, thrombophlebitis, insomnia, headaches, neuroses, migraines, auditory neuritis, radiculitis, myositis, rheumatism and many other diseases. However, there are contraindications associated with the fact that the leech allocates a special substance - hirudin, slowing blood coagulation. For individuals with hemophilia leech bites can cause death. In addition, leeches are contraindicated in patients with iron deficiency anemia, people with reduced pressure, pregnant women and cancer patients. In addition, it is not worth to use leeches for children up to seven years old.

For therapeutic purposes, other animals are used.

A simple observation of aquarium fish saves people from depression, nervous breakdowns or severe psychological shocks. Observing birds and listening to their choir positively affects the nervous system: calms, comforters, aligns breathing and heart rate. Hamsters, guinea pigs, chinchillas, decorative rabbits, can help uncertain people to overcome isolation and defeat complexes. Communicating with them configures a person into an open and friendly way. In addition, tactile contact with small fluffy and soft animals reduces fine muscles, which in turn reduces anxiety, emotional tension and aggression. Observation and tactile contact with reptiles strengthens the nervous system, organizes emotions, helps the person during neurasthenia, chronic pneumonia, epilepsy and neurodermatitis [Ошибка! Источник ссылки не найден., Ошибка! Источник ссылки не найден.].

It is proved that the interaction of the child with animals contributes to the successful merger of the child with the society, forms its competence, normalizes the nervous system, relieves fear and aggression, relieves anxiety and stress, stimulates interpersonal relationships [Ошибка! Источник 
Хохлова М. Г., Немова Т. В., Цвіліховський М. І.

ссылки не найден., Ошибка! have high chances to become socially Источник ссылки не найден.].

Discussion. Animals and their active people and psychologically healthy individuals in the future.

Animal-assisted therapy, as a images carry out effective social and psychological assistance to both adults and children in solving a wide range of problems. Children who grow up in love with animals and can understand them,

\section{References}

1. Antonioli C. (2006). Animal therapy. Journal of Palliative Medicine. Aug., Vol. 9, Issue 4, 1012-1022.

2. Brodie S. (1999). Exploration of the potential benefits of pet-facilitated therapy. International Journal Nurs Study. Vol. 8., 329-337.

3. Antsupova I. (2006). Naznacheniie: loshad, koshka ili sobaka? [Purpose: a horse, a cat or a dog?]. Vokrug sveta. - Around the world. Vol. 12, 214-220.

4. Antsupova I. (2006). Animaloterapiia [Animal therapy]. Vokrug sveta. - Around the world. Vol. 12, (2795), 74-75.

5. Barsov S. (2004). Chetveronogiie tseliteli [Four-foot healers]. Chudesa i priklyucheniia Miracles and adventures. Vol. 9., 47-48.

6. Venger-Burlachenko M.P. (2016). Felinoterapiia. Terapevtichnoie riadom [Therapeutic - near]. Psikhologiia $i$ terapiia. - Psychology and Therapy. Retrieved from https://samopoznanie.ru/articles/felinoter apiya terapevtichnoe ryadom/

7. Verevkina O. V. (2017) Animaloterapiia kak innovatsionnyi i perspektivnyi metod psikhologicheskoi raboty [Animal therapy as an innovative and promising method of psychological work]. Elektronnyi nauchnyi zhurnal

"Apriori", ceriia: gumanitarnyie nauki. Electronic scientific journal "Apriori", series: Humanities. Vol 5.

8. Dolgopolov N. V. Apiterapiia drevnosti i $\mathrm{v}$ nashe vremia [Apitherapy of antiquity in our time.]. Retrieved from: https://docbee.jimdo.com

9. Yeremeyeva S. (2005). Domashniie tseliteli [Home healers]. Krest'yanka. - Peasant woman, Vol. 8, 170-171.

10. Karpova N. Animaloterapiia: obshcheniie $\mathrm{s}$ zhivotnymi kak lekarstvo / [Animal therapy: communication with animals as a medicine]. Retrieved from https://www.medweb.ru/articles/animalot erapiya-obshhenie-s-zhivotnymi

11. Kryazheva N.L. (2000). Kot i pes speshat na pomoshch. Animaloterapiia dlia detei [Cat and dog rush to the rescue. Animal therapy for children]. Akademiia Razvitiia Academy of Development.

12. Natsvlishvili N (2010). Khvostatyie terapevty [Tailed therapists]. Krestianka - Peasant woman. Vol. 6., P. 106-107.

13. Nikolskaia A.V., Ulianova N.A. (2009). Nenapravlennaia animaloterapiia. Pozitivnyie i negativnyie aspekty vzaimodeystviia $\mathrm{s}$ sobakoy $u$ detei i vzroslykh [Non- 
Хохлова М. Г., Немова Т. В., Цвіліховський М. І.

directional animalotherapy. Positive and negative aspects of interaction with the dog in children and adults]. AquariumPrint; Moscow. 117 p.

\section{Nesterova D.V. (2000).}

Koshkoterapiia: pushistoie lekarstvo [Koshkoterapiya: fluffy medicine]. M.: RIPOL klassik. 64 p.

15. Nikolskaia A. V. (2008). Animaloterapiia [Animal therapy]. Tez. mezhd. kongressa Psikhologicheskoie obespecheniie natsionalnykh proyektov razvitiia obshchestva:

opyt, innovatsionnyie tekhnologii, mentalnyie bariery. - Abstracts of Papers int. congress Psychological support of national projects of society development: experience, innovative technologies, mental barriers Kostroma, 39-42.

16. Pashchenko

Pchelolecheniie - metod, ne imeiushchii sebe ravnykh po effektivnosti [Bee treatment - a method that has no equal in efficiency]. Zdorovia i Dovgolittia. Health \& Dovgolitya. Retrieved from https://www.zid.com.ua/rus_creativewor $\mathrm{k} /$ pchelolechenye--metod-neymeyuschyj-sebe-ravnyh-poeffektyvnosty

ОСОБЛИВОСТІ ВИКОРИСТАННЯ ДОМАШНІХ ТВАРИН У ТЕРАПЕВТИЧНИХ ЦЛЯХ

М. Г. Хохлова, Т. В. Немова, М. І. Цвіліховський

Анотація. Анімалотерапія має важливе значення у лікуванні багатьох захворювань людини $i \epsilon$ затребуваною у розвинутих крайни світу. Застосування методів анімалотерапії у медичній практиці має свої особливості, які $\begin{array}{lr}\text { передбачають } & \text { використання } \\ \text { направленої } & \text { анімалотерапї }\end{array}$ взаємодію з тваринами в домашніх
17. Tagiieva E.M. (2017). Animaloterapiia - kak metod psikhokorrektsionnoi raboty $\mathrm{s}$ detmi doshkolnogo i shkolnogo vozrastov [Animal therapy - as a method of psychocorrective work with children of preschool and school age]. Proceeding of scientific-practical. Conf. "Actual problems of modern psychology". Bakinskiy slavyanskiy universitet, Young Scientist. Vol. 14 (148), 21-23.

18. Ustiantseva T.( 2010). Ob umenii zhivotnykh vrachevat lyudei [On the ability of animals to heal people]. Diskaveri. - Discovery. Vol. 8, 84-87.

19. Tsvetkova M. V. (2013). Vliyaniie animaloterapii na detey $\mathrm{s}$ ogranichennymi vozmozhnostiami zdorovia $\mathrm{v}$ detskikh domakh [Influence of animal therapy on children with disabilities in children's homes]. Molodoi uchenyi. - Young Scientist. Vol. 4, 623-625.

20. Sharonova Ye.G. (2005). Sotsialnaia reabilitatsiia shkolnikov pri vzaimodeystvii $\mathrm{s}$ prirodoy [Social rehabilitation of students in interaction with nature]. Pedagogika. - Pedagogy. Vol. 6, 55-59.

умовах без усвідомлення або иілеспрямованого розуміння їх терапевтичного значення, або застосування анімалотерапії, щуо передбачає иілеспрямоване використання тварин $i$ їх символів за спеціально розробленими терапевтичним програмами 3 використанням спеціально навчених тварин. Метою роботи був ретельний аналіз методів inomepanii, каністерапіï, дельфінотерапії, гірyдотерaniï, animepaniï ma $\ddot{i x}$ 
Хохлова М. Г., Немова Т. В., Цвіліховський М. І. особливостей їх застосування $у$ різних сферах лікарської практики.

У роботі проаналізовано основні механізми дії методів анімалотерапї на організм людини та окреслено коло захворювань, які піддаються терапевтичному впливу за допомогою тварин. Встановлено високу ефективність застосування методів анімалотерапї для дорослих $і$ дітей y вирішенні иирокого кола медичних проблем. Відмічено, щуо застосування тварин різних видів у якості терапії дозволяе знімати стрес, нормалізуе роботу нервової системи, сприяе гармонізаиії міжсособистісних відносин та взаємодії особистості 3 навколишнім світом, щзо сприяе як психічній, так $i$ соизіальній реабілітації, а також реалізації внутрішнього потенціалу людини.

Анімалотерапія, як метод терапіі багатьох захворювань, має великі перспективи застосування, а також иирокий спектр вивчення особливостей дї тварин на організм людини.
Ключові слова: анімалотерапія, inomepaniя, дельфінотерапія, каністерапія, фелінотерапія, гірудотерапія, апітерапія, людина

\section{ОСОБЕННОСТИ ПРИМЕНЕНИЯ ДОМАШНИХ ЖИВОТНЫХ В ТЕРАПЕВТИЧЕСКИХ ЦЕЛЯХ М. Г. Хохлова, Т. В. Немова, Н. И. Цвилиховский \\ Аннотация. Анималотерапия} имеет важное значение в лечении многих заболеваний человека и является востребованной в развитых странах мира. Применение методов анималотерапии в медицинской практике имеет свои особенности, которые предусматривают использование не направленной анималотерапии, то есть взаимодействие с животными в домашних условиях без осознания или цуеленаправленного понимания их терапевтического значения, или применения направленной анималотерапии, что предполагает 
Ветеринарна медицина, якість і безпека продукції тваринництва

Хохлова М. Г., Немова Т. В., Цвіліховський М. І.

целенаправленное использование

животных $u$ uх символов по

специально разработанным

терапевтическим программами $c$

использованием специально обученных

животных. Целью работы был

тимательный анализ методов

иппотерапии, дельфинотерапии,

канистерапии, фолинотерапии,

гирудотерапии, апитерапии $u$ ux особенностей их применения в различных сферах врачебной практики.

B работе проанализированы основные механизмы действия методов анималотерапии на организм человека и очерчен круг заболеваний, которье поддаются терапевтическому воздействию с помощьью животных.Установлена высокая эффективность применения методов анималотерапии для взросльх и детей в решении иирокого круга медицинских проблем. Отмечено, что применение животных разных видов в качестве терапии позволяет снимать стресс, нормализует работу нервной системы, способствует гармонизации межличностных отношений $u$ взаимодействия личности $с$ окружаюшим миром, способствует как психической, так и сочиальной реабилитациии, а также реализациии внутреннего потенциала человека.

Анималотерапия, как метод терапии многих заболеваний, имеет большие перспективы применения, а также иирокий спектр изучения особенностей действия животных на организм человека.

\section{Ключевые}

слова:

анималотерапия, иппотерапия, дельфинотерапия, канистерапия, фелинотерапия, гирудотерапия, апитерапия, человек

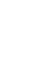

